\title{
What do users really want?
}

\author{
Saumya RamaRao \\ Population Council \\ John Townsend \\ Population Council \\ James Sailer \\ Population Council
}

Follow this and additional works at: https://knowledgecommons.popcouncil.org/departments_sbsr-rh

Part of the Gender and Sexuality Commons, International Public Health Commons, Maternal and Child Health Commons, and the Women's Health Commons How does access to this work benefit you? Let us know!

\section{Recommended Citation}

RamaRao, Saumya, John Townsend, and James Sailer. 2017. "What do users really want?" presentation at 2017 Family Planning Summit, London. 


\section{POPULATION}

\section{COUNCIL}

Ideas. Evidence. Impact.

\section{WHAT DO USERS REALLY WANT?}

Saumya RamaRao, John Townsend, and Jim Sailer

Symposium on "Bridging the Gap to FP2020: Evidence to Accelerate Progress"

July 10, 2017 


\section{Contributing to FP2020's Goals}

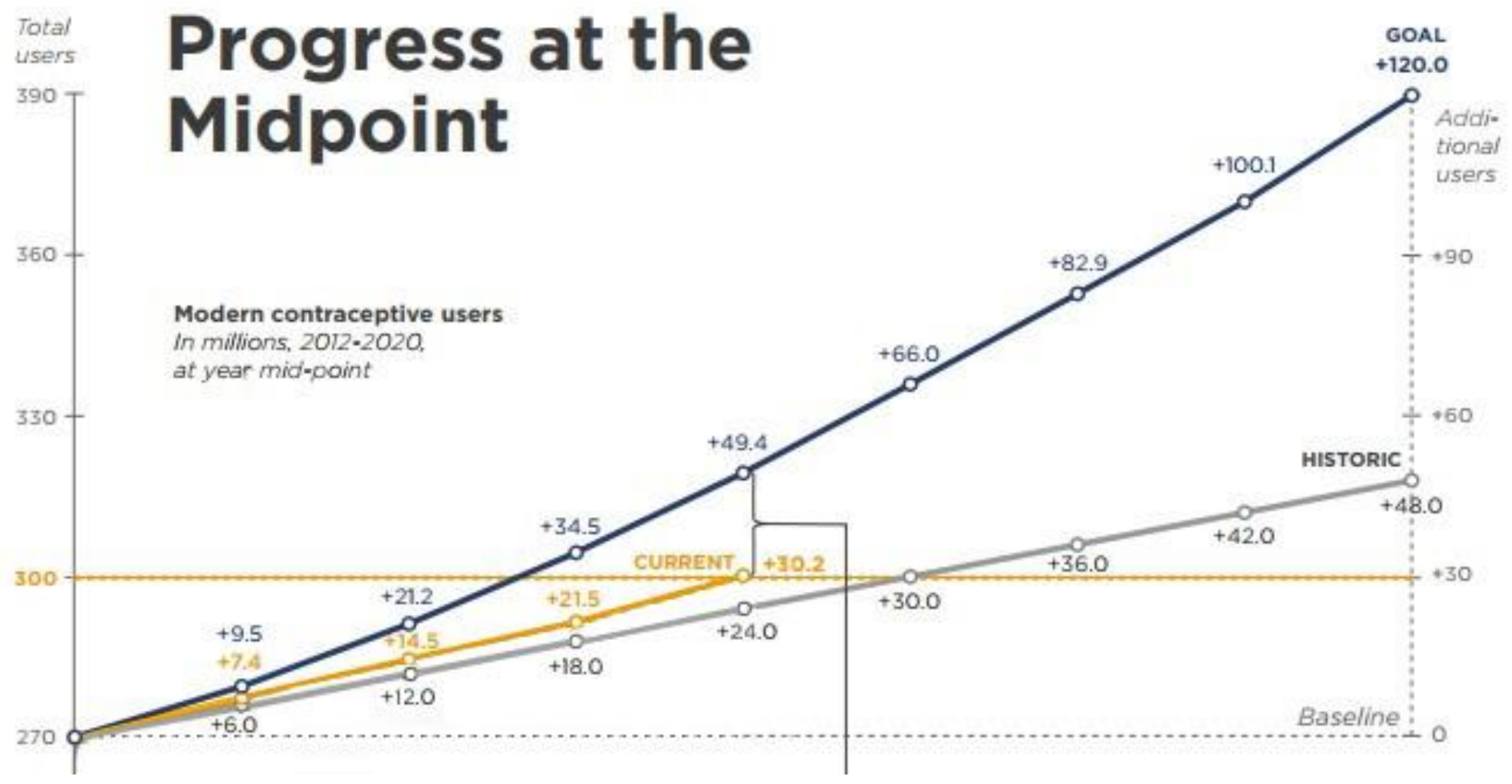

Source: FP2020 (http://progress.familyplanning2020.org/page/pace-of-progress/introduction1) 


\section{One-fourth of women wanting to avoid a pregnancy are not using modern contraceptives}

214 million have an unmet need for modern contraception

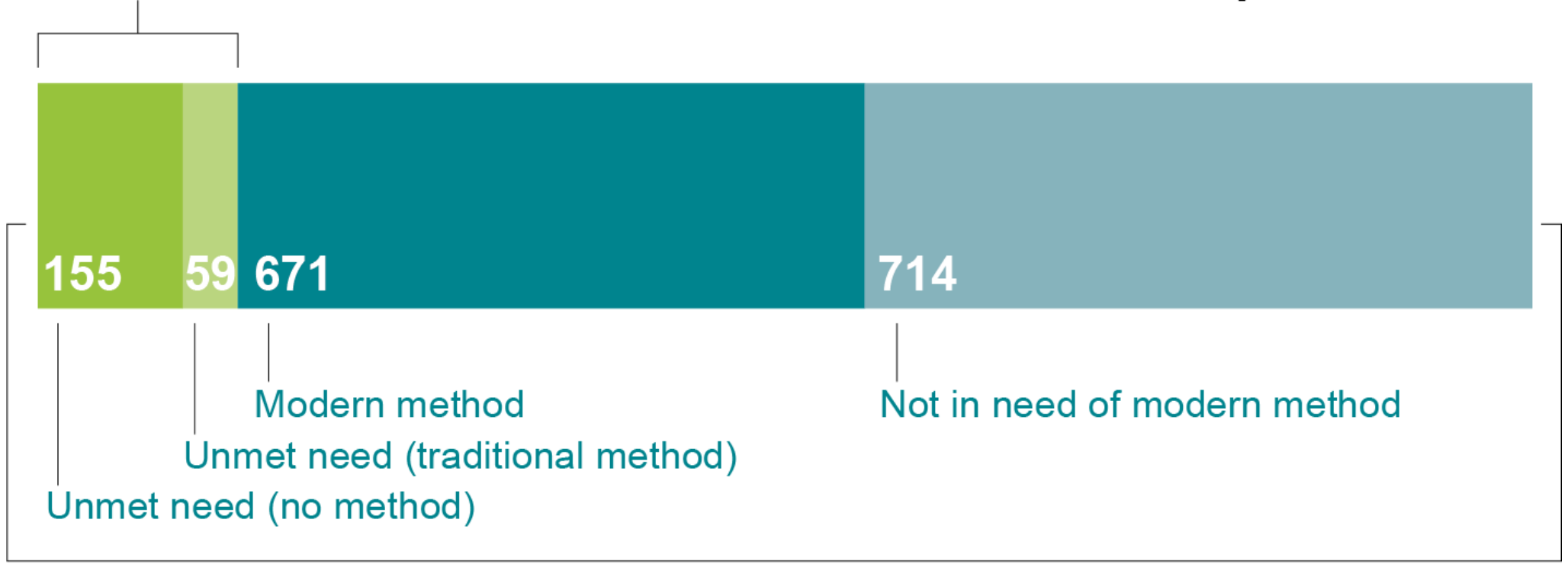

1,600 million women of reproductive age, 2017 


\section{Women with unmet need for modern contraceptives account for $84 \%$ of unintended pregnancies}

89 MILLION UNINTENDED PREGNANCIES, 2017

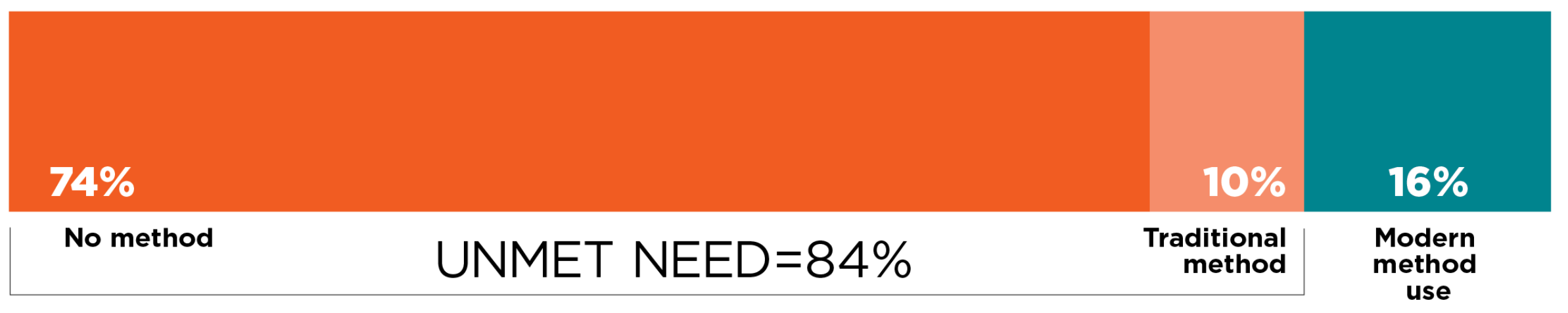

METHODS WOMEN USED WHEN THEY BECAME PREGNANT 


\section{CONTRACEPTIVE DISCONTINUATION:} REASONS, CHALLENGES, AND SOLUTIONS

A NEW REPORT FROM THE POPULATION COUNCIL \& FAMILY PLANNING 2020 HIGHLIGHTS WAYS TO BETTER MEET THE NEEDS OF WOMEN TO REDUCE DISCONTINUATION AND ENHANCE SWITCHING TO NEW METHODS.
Among women reporting a current unmet need for modern contraception: 1/ HAD USEDA MODERN $1 / 3$ METHOD IN THEPAST USEWITHIN 1 YEAR

\section{1/ STOPPED 2 YEARS}

KEY INTERVENTIONS TO IMPROVE SERVICE ENVIRONMENTS

\begin{tabular}{|l|l|l|l|l} 
INCREASE THE & $\begin{array}{l}\text { Adding one method to a program leads } \\
\text { NUMBER OF } \\
\text { AVAILABLE } \\
\text { METHODS }\end{array}$ & $\begin{array}{l}\text { to an } 8 \% \text { decrease in contraceptive } \\
\text { discontinuation. }\end{array}$ \\
\hline & $\begin{array}{l}\text { ENABLE WOMEN } \\
\text { TO SWITCH } \\
\text { IMMEDIATELY }\end{array}$ & $\begin{array}{l}\text { Women who experience problems must } \\
\text { be able to change to a preferable method } \\
\text { mmmedlately. }\end{array}$
\end{tabular}

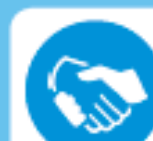

INCREASE ACCESS POINTS

Increasing the number and types of suppliers and providers can support informed choice and switching if needed.

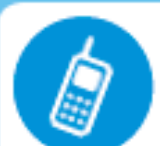

STRENGTHEN

FOLLOW-UP

MECHANISMS

Reminding women of appointments, e.g. through moblle technologles, can reduce unintentional discontinuation.

BRING THE

METHODS TO

WOMEN

Outreach services that take the method to the client can help women continue to use their method of choice even if they face tme or transportation challenges.

KEY INTERVENTIONS TO ADDRESS MYTHS AND SIDE EFFECTS

$\square \begin{aligned} & \text { ENABLE } \\ & \text { DISCUSSION OF } \\ & \text { POTENTIAL SIDE } \\ & \text { EFFECTS }\end{aligned}$

Discussing side effects with providers and the community can mprove understanding of the method, increase continuation, and better facilitate method switching.

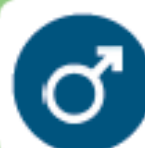

ENGAGE MALE PARTNERS

Enhanced couple communication can be effective in supporting continued use, particularly postpartum.

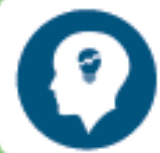

DISPEL

Serv loe providers should dispe misconceptions about the timing of starting MISCONCEPTIONS or sw Itching a method and the percewed need for hormonal method "rest periods."

\begin{tabular}{l|l|l} 
ENSURE CLIENT & $\begin{array}{l}\text { Because, in some settings, opposition to } \\
\text { family planning can be an issue, ensuring } \\
\text { client confidentlality must be a critical } \\
\text { priority. }\end{array}$
\end{tabular}

COUNSEL

WOMEN ABOUT PROLONGED AMENORRHEA
Reassurewomen who are plamng to become pregnant $\boldsymbol{n}$ the future that their menses will return to normal and educate about the average timing. 


\section{Rationale for Expanded Choice}

- Contraceptive needs change over time and across individuals

- Facilitate contraceptive switching for those who still want to avoid pregnancy

- 38\% of women discontinue use by 12 months

- Address preferences of new generations of users-“Not my grandmother's contraceptive"

- 1.8 billion young people with different aspirations for life, health, and wellbeing 


\section{Introduce and Expand Access to} Existing Contraceptives

- Access increases

with task shifting to lower level providers

- Volume guarantee by donors energized implant market

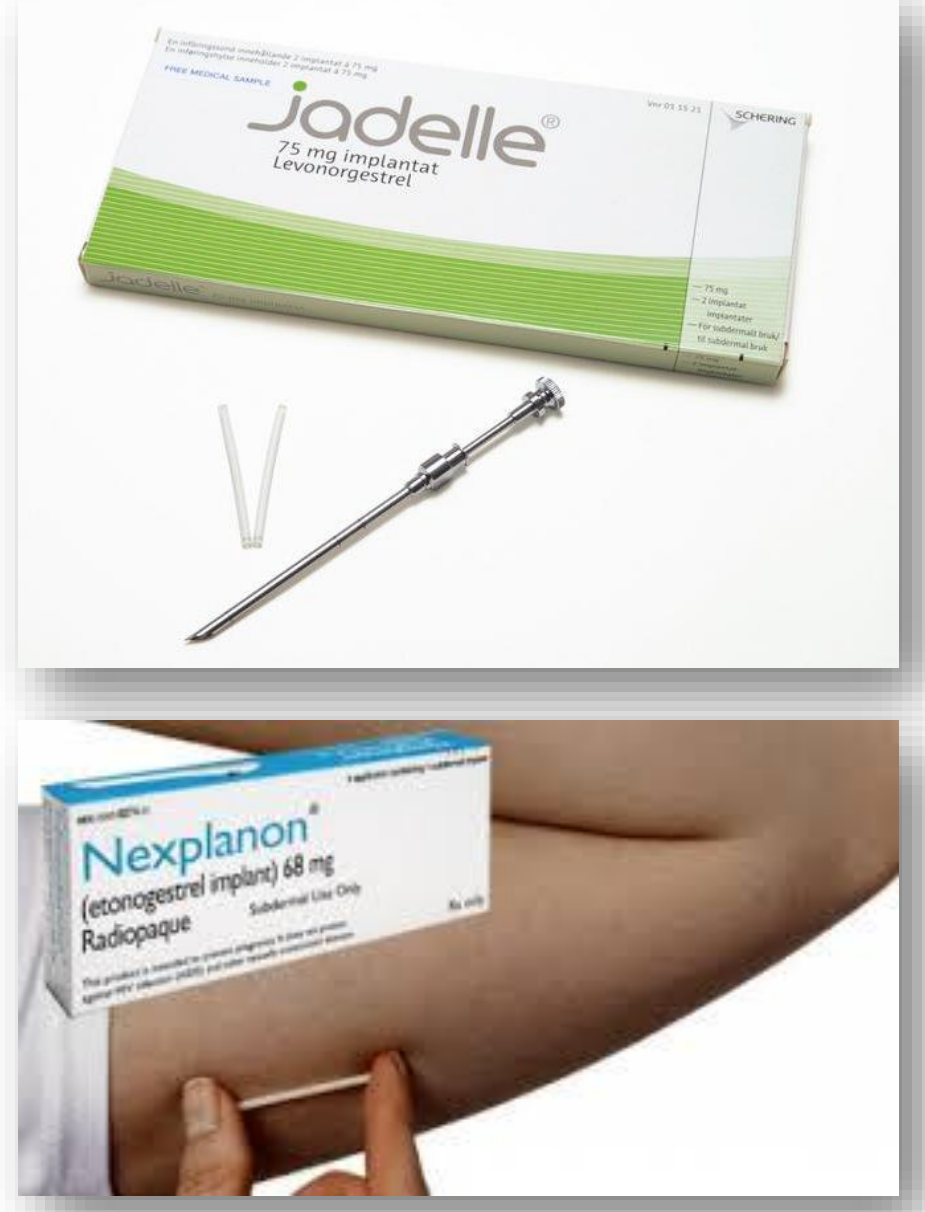




\section{Adapt Existing Contraceptives}

- Sayana Press for self-use and delivery by community-based health providers

- SILCS diaphragm incorporated user inputs for improved design
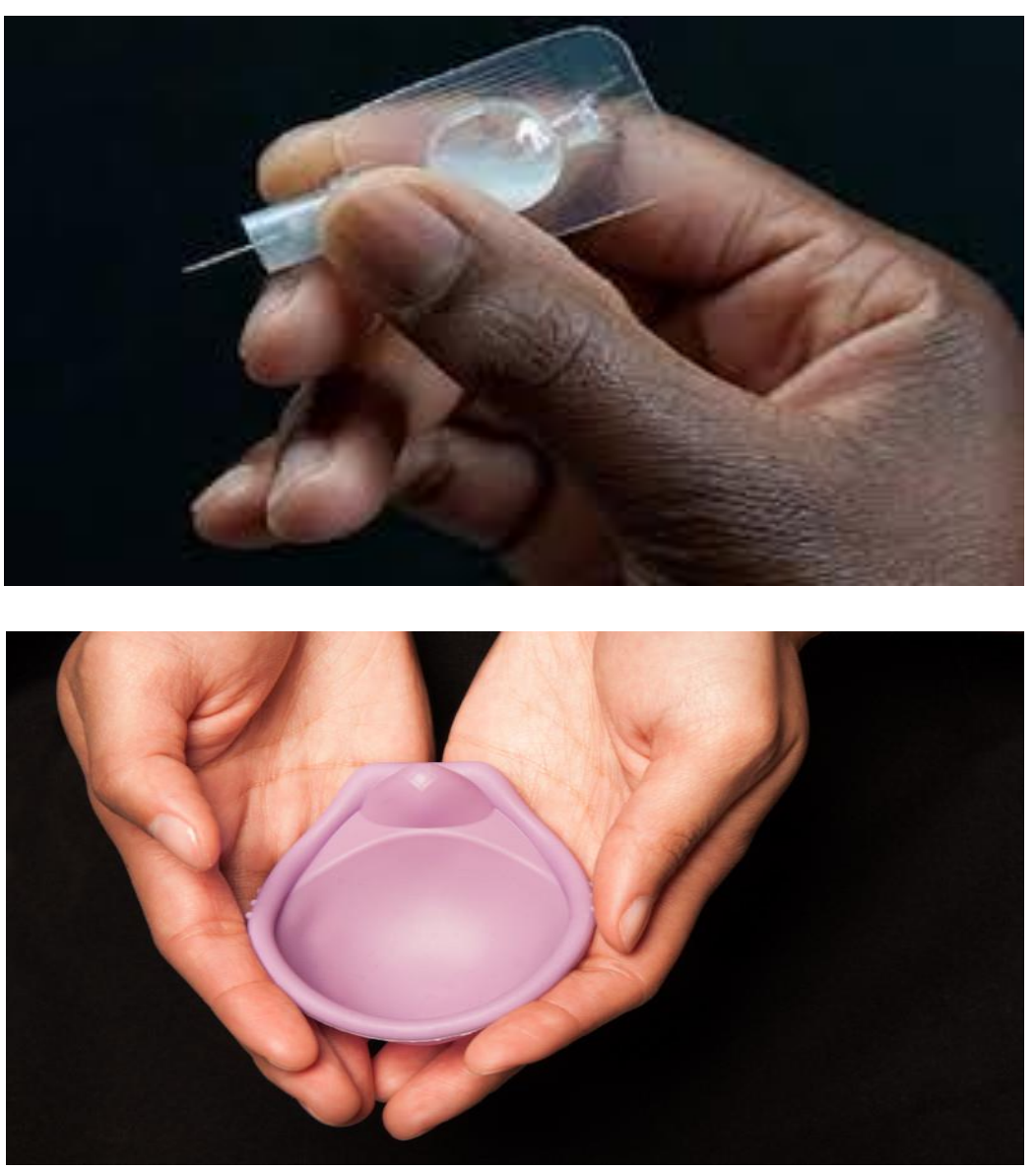


\section{New Technologies: Contraceptive Vaginal Rings}

- 3-month ring that contains natural progesterone for use by breastfeeding women

- Investigational combined ring that prevents pregnancy for 1 year

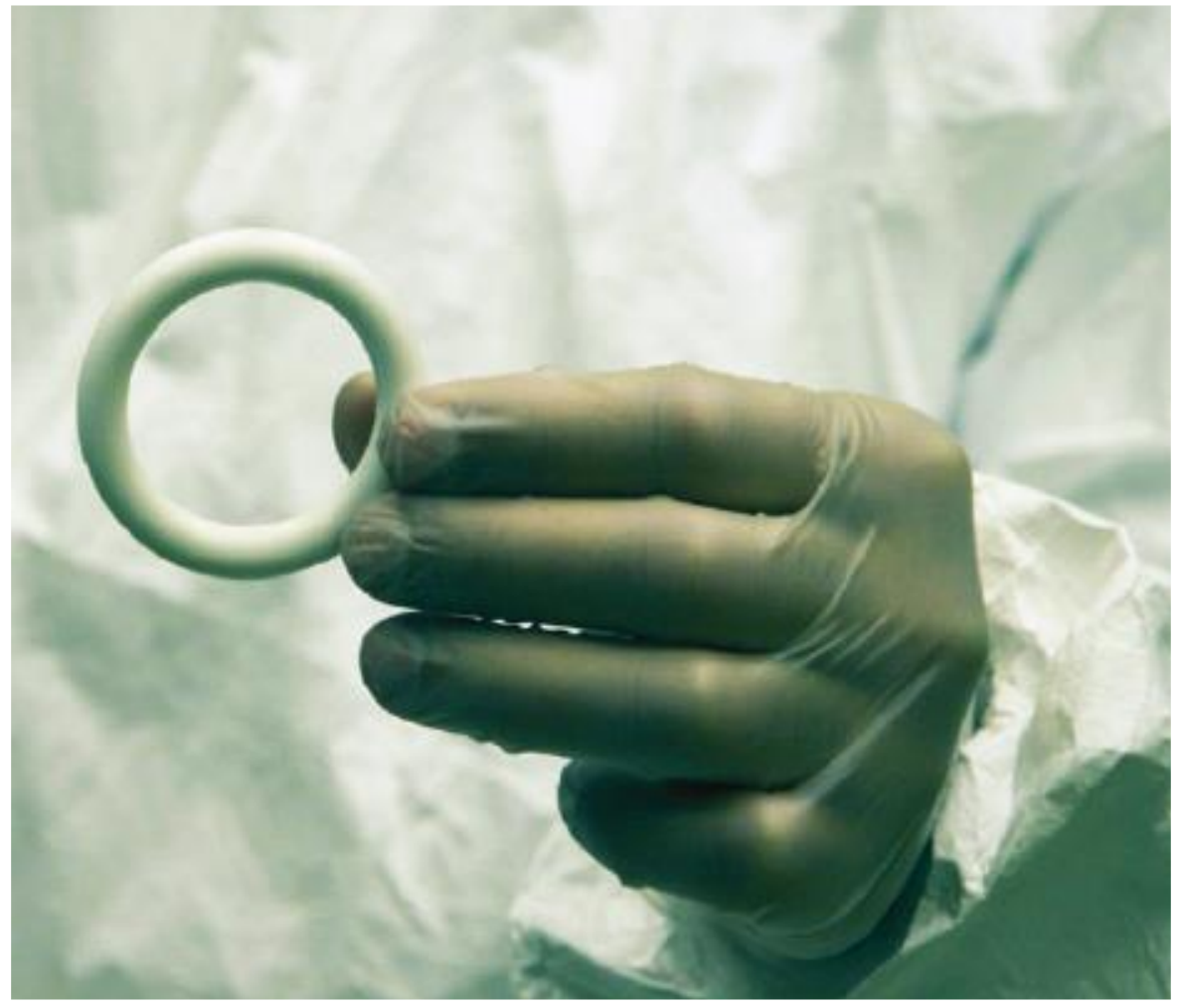


Considerations for Product

\section{Development}

- Fewer side-effects

- E.g., better bleeding cycles

- Improved user experience and autonomy

- E.g., self use, convenience, multiple drug delivery formats

- Offer multiple health benefits

- Address men's needs for contraception

- Lower cost to consumers and procurers 


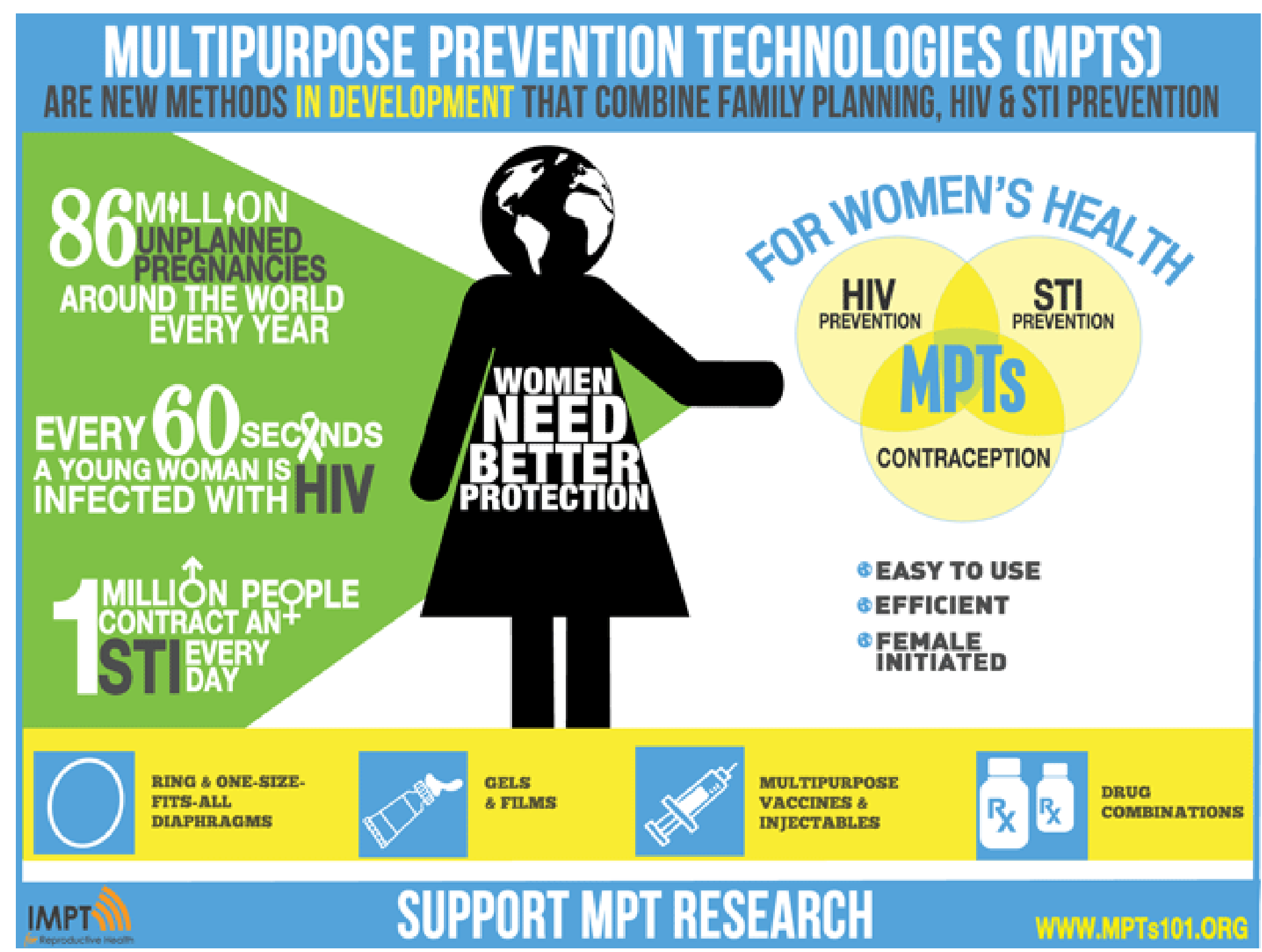




\section{Multipurpose Prevention Technologies: Pregnancy and STI/HIV Prevention}

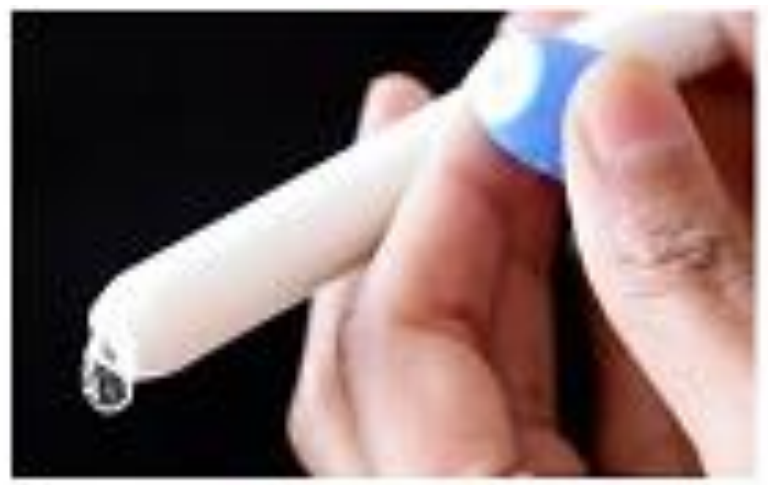

Gel

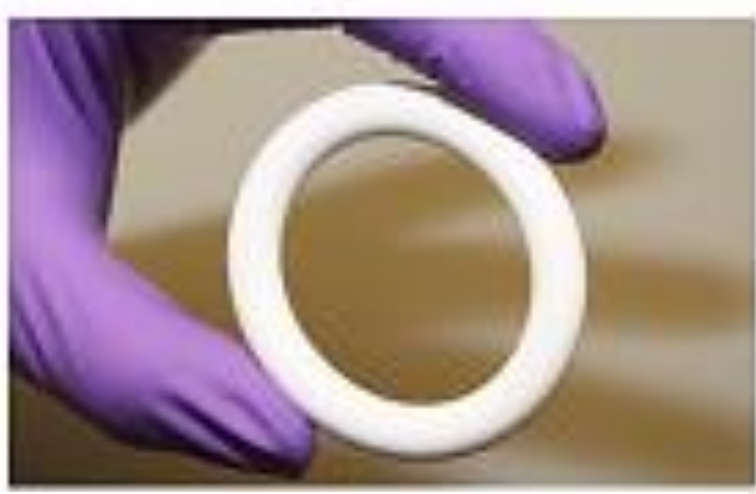

Intravaginal ring

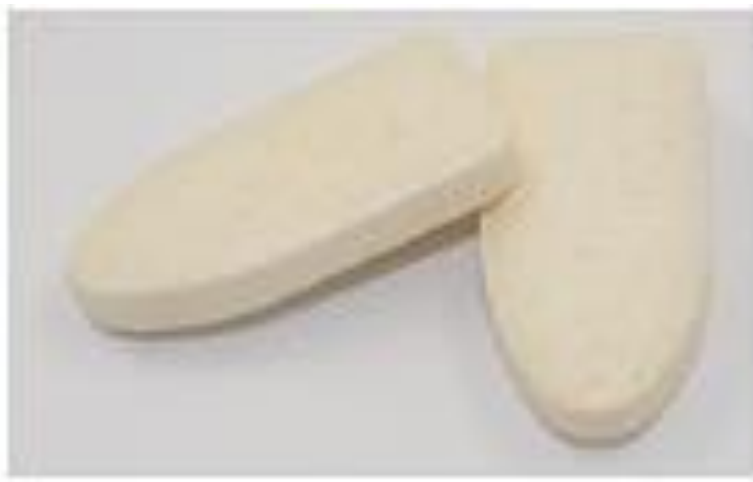

Fast dissolve insert

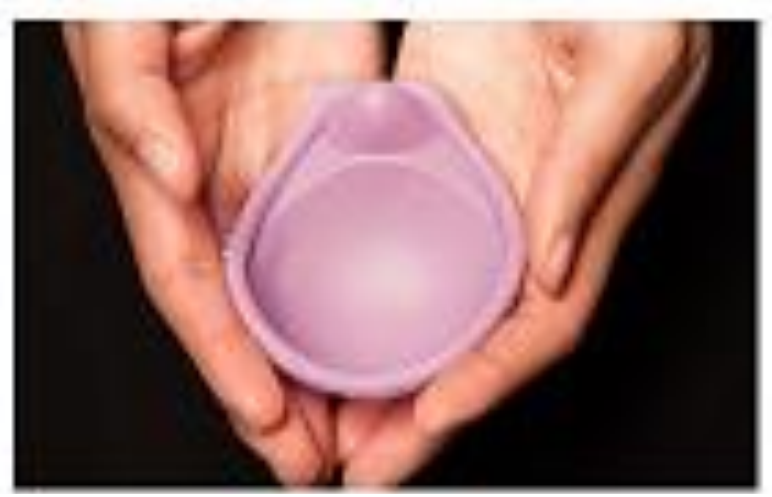

SILCS Diaphragm + Gel 


\section{Male Contraception in Discovery}

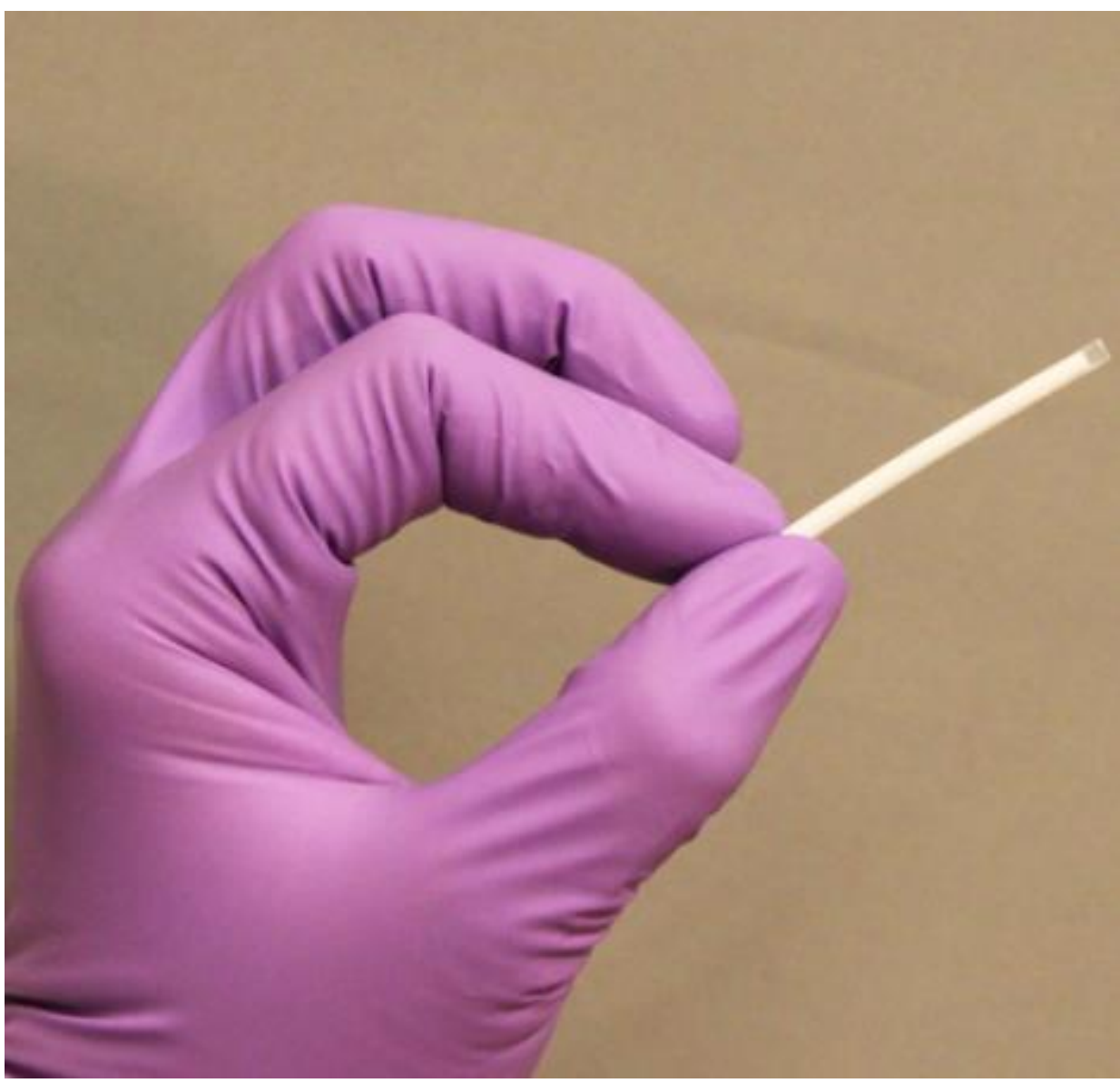

- Developing 1 year, reversible hormonal contraceptive implant for men containing novel androgen, MENT®

- Early clinical trials, showing promising results

- Would give men longer-term options 


\section{Male Contraception}
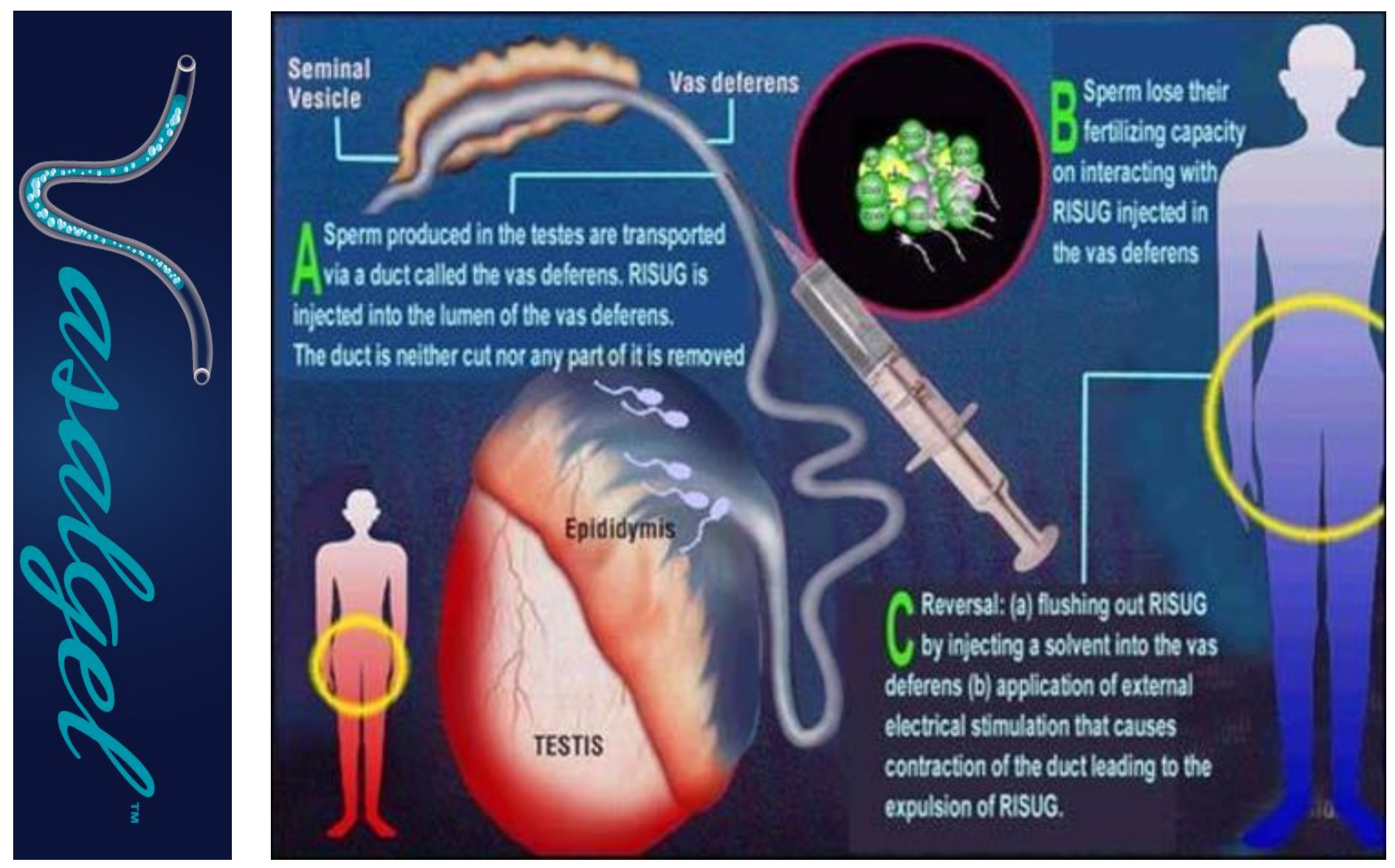


\section{Make healthy behaviors appealing}

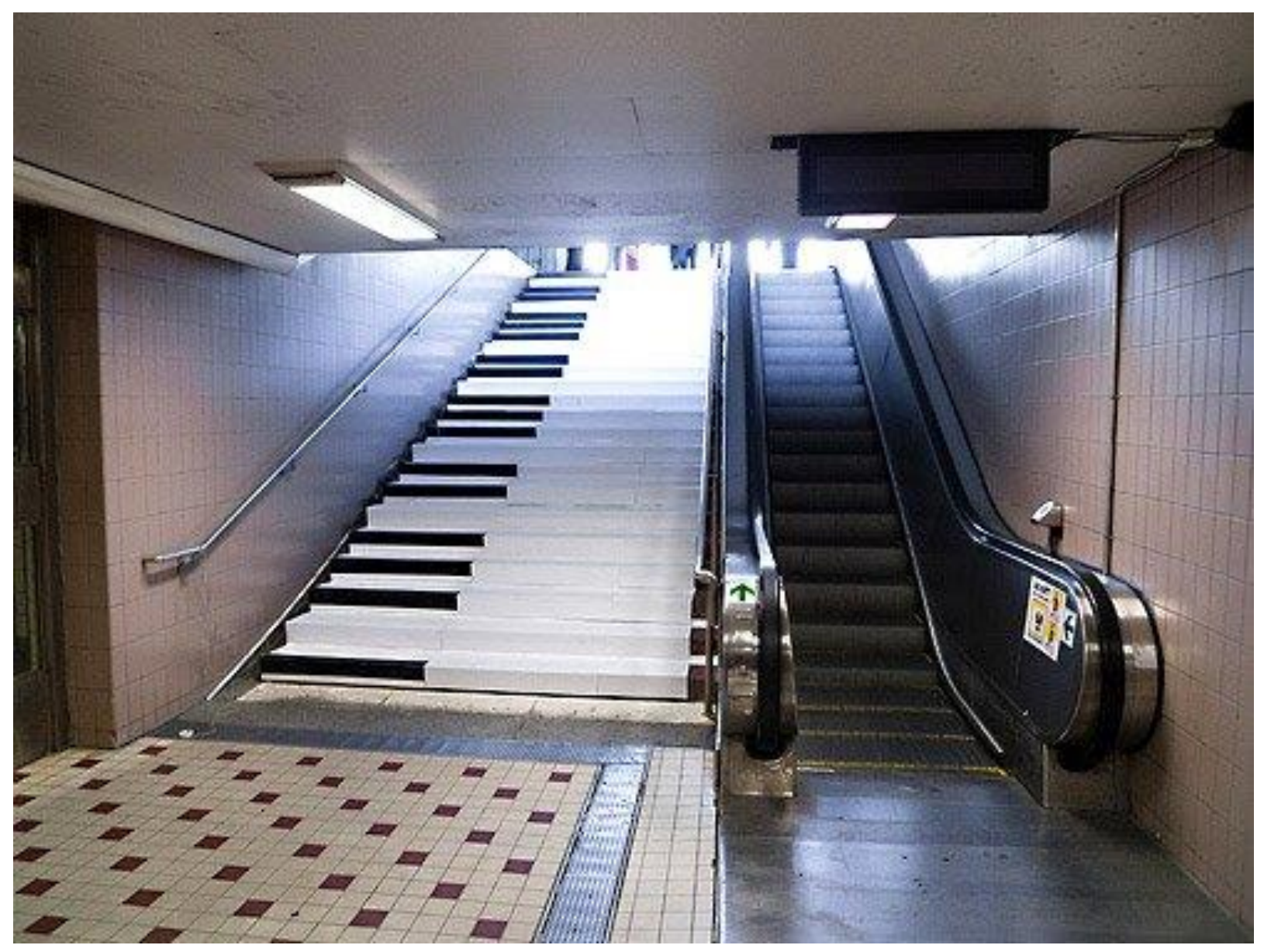

Subway Piano Stairs - Odenplan Stockholm 
- POPUlation

\section{Promise of New Contraceptives}

- Helps users realize their reproductive intentions

- Achieves health system efficiencies

- Energizes markets

- Contributes to FP2020 goals

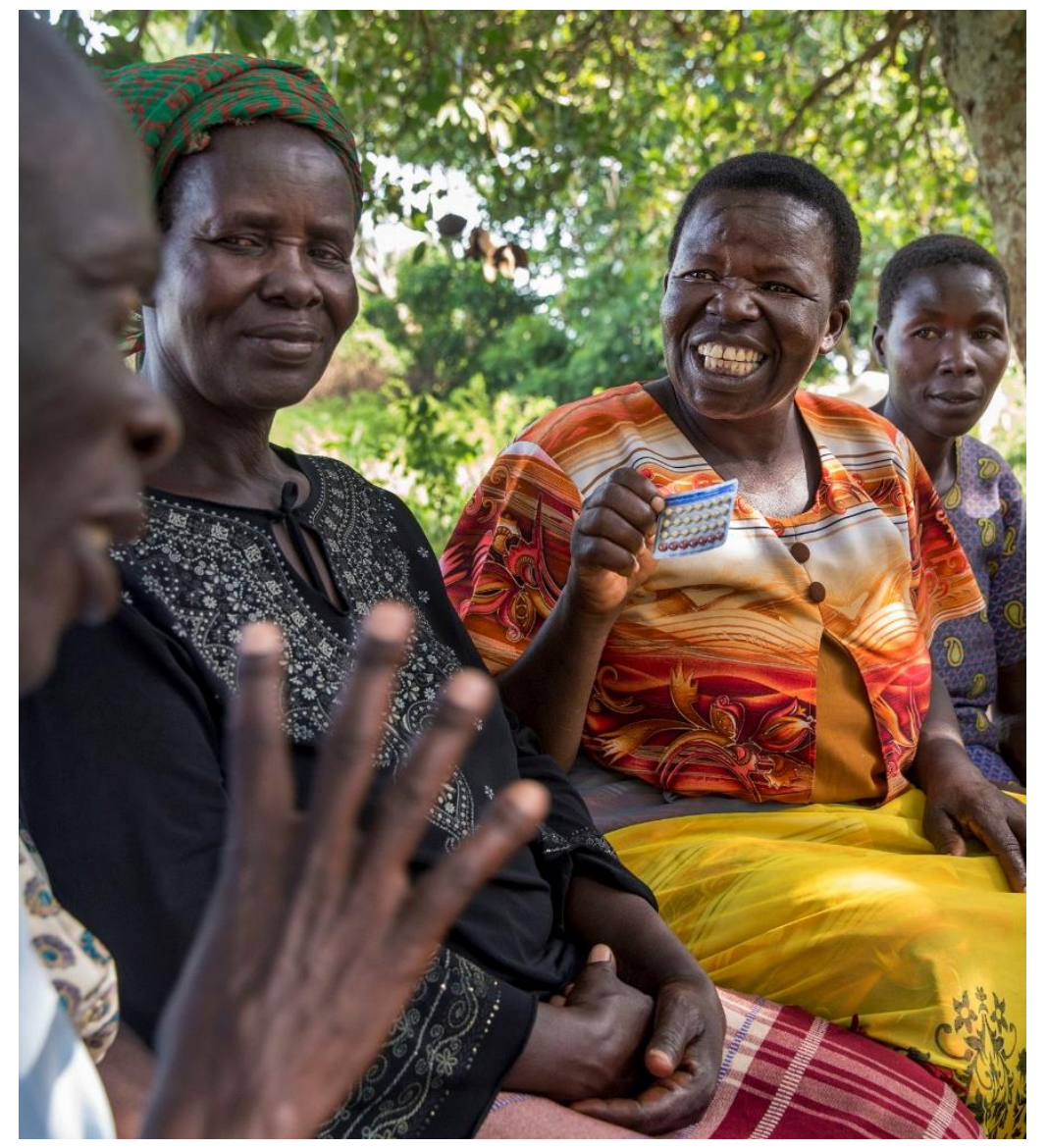

Courtesy of Jonathan Torgovnik/Getty Images Reportage. Some rights reserved. 


\section{Ideas. Evidence. Impact.}
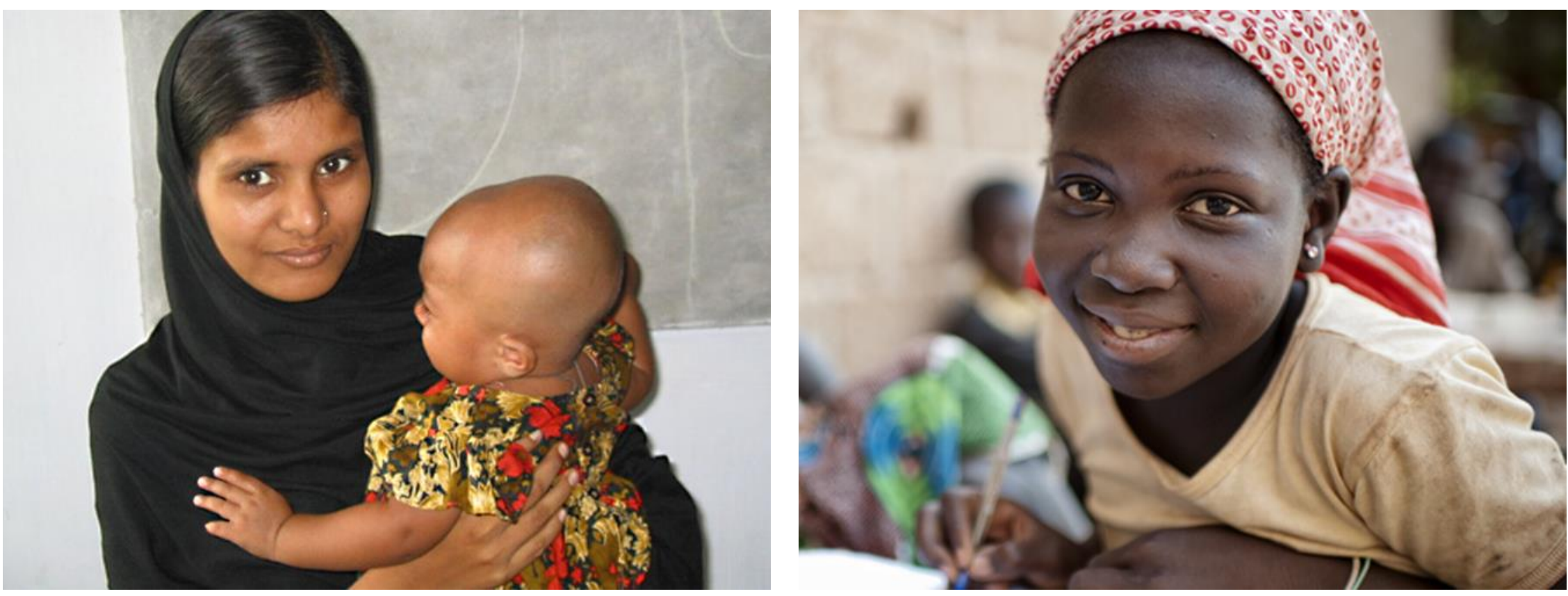

The Population Council conducts research and delivers solutions that improve lives around the world. Big ideas supported by evidence: It's our model for global change. 